\title{
Implementations of digital technologies in COVID -19 pandemic and other health
}

\section{threats: multi nationals responses}

\author{
Implementações de tecnologias digitais na pandemia de COVID-19 e em outras ameaças à saúdle: \\ respostas multinacionais \\ Implementaciones de tecnologías digitales en la pandemia COVID -19 y en otras amenazas a la
} salud: respuestas de las multinacionales

Received: 10/14/2021 | Reviewed: 10/24/2021 | Accept: 10/26/2021| Published: 10/30/2021

\author{
Krishna Prasad Pathak \\ ORCID: https://orcid.org/0000-0001-7062-4976 \\ Nepal Open University, Nepal \\ Universidade Federal de São Paulo, Brasil \\ E-mail: krishnapathak2075@gmail.com \\ Tara Gaire \\ ORCID: https://orcid.org/0000-0003-3524-5705 \\ Innovative College of Health Science, Nepal \\ E-mail: taragaire33@gmail.com \\ Alphonse Laya \\ ORCID: https://orcid.org/0000-0003-0755-6282 \\ University of Maroua, Cameroon \\ E-mail: laya.alphonse@yahoo.fr \\ Alessandra Paula Ferreira Moreira Neumann \\ ORCID: https://orcid.org/0000-0002-6182-9598 \\ Universidade Federal de São Paulo Brasil \\ E-mail: neumann.alessandra@unifesp.br \\ Mônica de Souza Brito Conti \\ ORCID: https://orcid.org/0000-0002-4810-7566 \\ Universidade Federal de São Paulo, Brasil \\ E-mail: monibrito@hotmail.com \\ Frederico Molina Cohrs \\ ORCID: https://orcid.org/0000-0002-6556-6852 \\ Universidade Federal de São Paulo, Brasil \\ E-mail: fcohrs@unifesp.br \\ Maria Aparecida Ferreira de Mello \\ ORCID: https://orcid.org/0000-0001-9542-3134 \\ Technocare, Soluções e Tecnologia Assistiva, Brasil \\ E-mail: mariademello@technocare.net.br \\ Emanuela Bezerra Torres Mattos \\ ORCID: https://orcid.org/0000-0002-1780-2355 \\ Universidade Federal de São Paulo, Brasil \\ E-mail: emattos@unifesp.br \\ Luiz Roberto Ramos \\ ORCID: https://orcid.org/0000-0003-3143-8315 \\ Universidade Federal de São Paulo, Brasil \\ E-mail: 1rramos1953@gmail.com
}

\begin{abstract}
COVID-19 has created enormous challenges for health systems around the world. An immense range of digital health technologies has been considered as strategies. The aim of this article is to describe the implementation of digital technologies during the COVID-19 pandemic in prevention, diagnosis and treatment globally. Relevant articles published electronically in English using the following terms "COVID-19", "2019-nCov", "coronavirus", terminologies, "severe acute respiratory syndrome 2", SARS-CoV-2", "access to digital health, telemedicine and ehealth, challenges and opportunities, in different data sources were researched. A total of 455 articles were found, and 46 published articles about prevention, treatment, and diagnosis approaches were selected. Digital technologies were useful in holistic control, care management and prevention, digital information, data collection, transfer and storage, frontline protection, risk reduction, analysis and adequate system of monitoring information during the pandemic situation, applying teleservice, consultations to specialists via online/offline, intelligent health system, which decreased the burden of patients to health professionals in institutions. In addition, it helped provide safe, rapidly and
\end{abstract}


adequate patient data; and to avoid contamination for healthcare providers, the general population and patients. Still, the use of digital technologies in health is insufficient in many countries. It is essential to expand alternative ways of adapting digital technologies in health practices, but also to implement other studies on the use of digital health technologies beyond the focus on COVID-19.

Keywords: COVID-19; Digital technologies; Pandemic; Challenges; Opportunities.

\section{Resumo}

A COVID-19 criou enormes desafios para os sistemas de saúde em todo o mundo. Uma imensa gama de tecnologias digitais em saúde tem sido considerada como estratégias. $\mathrm{O}$ objetivo deste artigo é descrever as implementações de tecnologias digitais durante a pandemia de COVID -19 na prevenção, diagnóstico e tratamento globalmente. Foram pesquisados artigos relevantes publicados eletronicamente em língua inglesa usando os seguintes termos "COVID19", "2019-nCov", "coronavírus", terminologias, "síndrome respiratória aguda grave 2", SARS-CoV-2", " acesso a saúde digital, telemedicina e e-saúde, desafios e oportunidades, em diferentes fontes de dados. Foram encontrados 455 artigos, sendo selecionados 46 publicados acerca de abordagens de prevenção, tratamento, e diagnóstico. As tecnologias digitais foram úteis no controle holístico, gerenciamento da atenção e prevenção, informações digitais, coleta, transferência e armazenamento de dados, proteção de linha de frente, redução de riscos, análise e sistema adequado de informações de monitoramento durante a situação pandêmica, aplicando teleatendimento, consultas aos especialistas via online/offline, sistema de saúde inteligente o que diminuiu a sobrecarga dos pacientes aos profissionais de saúde nas instituições. Além disso, ajudou a fornecer dados seguros, de forma rápida e adequados dos pacientes; e a evitar a contaminação para prestadores de cuidados de saúde, população em geral e pacientes. Ainda assim, o uso de tecnologias digitais em saúde é insuficiente em muitos países. É fundamental ampliar formas alternativas de adaptação das tecnologias digitais nas práticas de saúde, mas também implementar outros estudos sobre o uso de tecnologias digitais de saúde para além do foco na COVID-19.

Palavras-chave: COVID-19; Tecnologia digital; Pandemia; Desafios; Oportunidades.

\section{Resumen}

La COVID-19 ha creado enormes desafíos para los sistemas de salud de todo el mundo. Una inmensa gama de tecnologías de salud digital se ha considerado. El objetivo de este artículo es describir la implementación de las tecnologías digitales durante la pandemia de COVID-19 en la prevención, el diagnóstico y el tratamiento a nivel mundial. Se investigaron artículos publicados electrónicamente en inglés utilizando los siguientes términos "COVID19", "2019-nCov", "coronavirus", "síndrome respiratorio agudo severo 2", SARS-CoV-2", "acceso a la salud digital, telemedicina y e-salud, desafíos y oportunidades, en diferentes fuentes de datos. Se encontraron un total de 455 artículos y se seleccionaron 46. Las tecnologías digitales fueron útiles en el control holístico, la gestión y prevención de la atención, la información digital, la recopilación, transferencia y almacenamiento de datos, la protección de primera línea, la reducción de riesgos, el análisis y el sistema adecuado de monitoreo de la información, la aplicación de teleservicios, las consultas a especialistas a través de internet / fuera de línea, el sistema de salud inteligente, que disminuyó la carga de los pacientes para los profesionales de la salud. Además, ayudó a proporcionar datos de pacientes seguros y rápidos; y evitar la contaminación para los proveedores de atención médica, la población general y los pacientes. El uso de las tecnologías digitales en salud es insuficiente en muchos países. Es esencial ampliar las formas de adaptar las tecnologías digitales en las prácticas de salud, pero también implementar otros estudios más allá del enfoque en COVID-19.

Palabras clave: COVID-19; Tecnologías digitales; Pandemia; Desafíos; Oportunidades.

\section{Introduction}

The outbreak of COVID-19 is pandemic disease globally (Zhu, et al., 2020) and declared as a public health emergency by the WHO worldwide (World Health Organization, 2019). All over the world, every government from every nation had made enormous efforts for providing an effective health care system as fast as possible to fight with this pandemic (Smith, et al., 2020). However, the highly developed countries are failing to overcome the pandemic issue as they predicted regarding the multidimensional consequences. In many countries it was enforced lockdown and social distancing as a tool for epidemic control (Pathak, et al., 2020).

Since the coronavirus pushed all the nations to jump to the digital world, most nations had adopted many digital procedures on the daily life, as for example online shopping and robot deliveries, digital and contactless payment, in order to decrease the risk of contagion. The use of digital technologies become part of daily life activities, with potential benefits to cognition, quality of life management and intervention programs to stimulate independence in daily life (Vicentin, et al., 2020). 
In the global scenario, telemedicine and other types of telecare have been used as a powerful health care tool (Kichloo, et al., 2020).

Historically, telemedicine started in 1948 when the first Radiological Images was sent via telephone in a distance of 24 miles (Gershon-Cohen \& Cooley, 1950). In 1959, the University of Nebraska, USA, used telemedicine to transmit neurological examinations, which was applied for the first case of health professionals using the telephone to send and receive medical documents across long distances (Benschoter, et al., 1967). In the 1960s: Nebraska Psychiatry Institute used closedcircuit TV for psychiatric consultations. During the 1960s, numerous accounts of wireless transmission of Electrocardiogram (ECG), cardiac monitoring, and even X-ray images were reported (Monnier, et al., 1965). In 1961, the U.S. conducted the Space Program to test animals of flights via computer network allowing healthcare professionals send and share information. This helped to put down the base of the modern Telehealth care system.

In 1968, a telemedicine project was activated by nurses, and was given the "medical station" to assess at the airport and Massachusetts General Hospital to provide primary and emergency services to passengers and airport personnel (Murphy \& Bird, 1974). Likewise, in 1993 was established an American Telemedicine Association (Jared, 2020). In the 1990s, the use of internet drastically innovated the tele health care system, making possible the use of digital technologies globally. In the beginning, telemedicine was the application of traditional physician-patient (and physician-physician) interactions (video and audio communications). Later on, information and communication technology (ICTs) extended on care services, including training health care professionals and health information to all levels (Bashshur, et al., 2011). World Health Organization in 2010, stated that telemedicine strategy in the delivery of healthcare services plays a crucial factor where the distance is a barrier. It is useful where modern technologies are lacking for valid diagnosis, treatment, prevention and continuous education for health professionals and communities as well (World Health Organization, 2010).

The term "digital health" (DH), or the use of digital technologies for health, had become a solution to address health needs unmet by the traditional modalities. eHealth has been used for sharing information to support health-related fields by using mobile and other wireless technologies in order to speed up the communication and crucial decisions. Digital health (DH) is an umbrella term encompassing multiple areas of science, such as computing sciences to keep data, genomics and artificial intelligence, electrocardiogram (ECG), Magnetic resonance imaging (MRI), and many other diagnosis and intervention procedures given the continuously developing 4G and 5G (Rheuban \& Krupinski, 2018).

Digital health also was stimulated as a save way to deal with communicable diseases during a pandemic through keeping social distancing (Xiao \& Fan, 2020). Telehealth can assist (or manage the burden) with remote screening and the facilities of care during such pandemic situations (Lurie \& Carr, 2018). Evidence has shown that in the healthcare system, digital health can improve the quality of access to healthcare, decrease the expenses, resulting in a better health provision for the users (Caffery, et al., 2016), and also it can contribute to decreasing the patients overload to the health care professionals in the institutions like hospitals, clinics. At the same time, positioning technologies, satellite monitoring, health sensors and apps, drones (drones were applied in carrying medicine and spraying disinfectants in agricultural farms) and 3D Printing which was deployed to mitigate the impact to the supply chain and export bans on personal protective equipment (Restás, et al., 2021) Other technologies as video conference platforms, big data and facial recognition, artificial intelligence, autonomous vehicles, mobile tracking/mass surveillance, were used also to mitigate the epidemic effects not only in the health system but also in the day to day life (Restás, et al, 2021).

The COVID-19 crisis also proved that emerging technologies like the internet of things and artificial intelligence are not just tools, they are essential to the functioning of our society in this 21 st century (Brem, et al., 2021), making the daily life easier including dealing with communicable disease. Digital technology enables both education and remote work for health workers and populations in specific time with limited resources and accurately. For example, the chatbots provide life-saving 
information and relieve overwhelmed health systems, location, map and the spread of the virus for health workers within a short time. That can save time, money to all the sectors and will be cost effective (Bettinger, 2020). However, it is necessary to seek more reliable proof to apply and implement the full potential of this growing area in health science (Rheuban \& Krupinski, 2018).

In spite of all use of technology supporting health service delivery, there is still a gap in the research demonstrating how digital health (DH) in medical interventions and implementation can be effective. This present study explored the access, opportunities and challenges of the application of digital health technologies during the COVID-19 pandemic. This papers have collected the papers those were published focusing on COVID-19 issue with using digital health technologies and were applied during the pandemic to inform the readers what was the approaches implemented by multinationals countries. It impacted rapidly throughout the globally. Thus, it is right time that all the nations should adapt digital health technologies to delivering the care based on digital technology which could change the health care dramatically for the developing world.

\section{Methodology}

The article was done by the research modality exploratory, qualitative, with bibliographic study. Exploratory research seeks to become familiar with the phenomena that arise during the research, more deeply and with greater accuracy (Rodrigues, 2007). In according with Machi \& McEvoy (2016) it was selected a topic, developed the tools, searched the literature, analyzed the literature and finally writing the review (Machi \& McEvoy, 2016). The review was done electronically, including published papers in English, using the following search terms: "COVID-19", "2019-nCov", "coronavirus", terminologies, "severe acute respiratory syndrome 2", SARS-CoV-2", "digital health", "telemedicine" and "ehealth" in PubMed and Google search engine up until february, 2021. The search was not restricted by study design, but should be peer reviewed.

These strategies were complemented with a comprehensive search of the 'grey' literature, about publications not published in indexed peer-reviewed journals, published in English. Also, it was searched by reference lists of published papers. It was excluded those studies that were not written on COVID issues with using digital health technologies. It was not limited to searching whether those technologies were developed before or after COVID, the focus was on the application of these technologies during COVID-19.

This literature review also aimed to answer the following questions: 1) what sorts of digital health procedures have been used in different countries; 2) what technologies supported the diagnose process, prevention, and treatment; and 3) in which countries the technologies were used in prevention, diagnose, and treatment. For this purpose, the papers analysis was divided into three categories: 1) Countries response and application of digital health approach; 2) Strengths, limitations and future scopes; and 3) significant digital health technologies which may help in COVID -19 outbreaks.

\section{Results and Discussion}

The results will be presented focusing on how the digital technologies were adopted during pandemic and how the countries were able to apply those technologies. It was found 455 articles from different databases focused on the digital health technologies use at the time of pandemic. From those, it was selected 46 published papers on the treatment, diagnosis and prevention approaches. It was included also found on the online papers, countries newspapers, health ministries and other health authorities published papers, and protocols. These are shown on tables 1, 2, 3, 4. It is worth mentioning that we consider digital technologies to meet public health needs, such as those turned into digital epidemiological surveillance, rapid case identification, interruption of community transmission, public communication, and clinical care. 


\subsection{Countries response and application of digital health approach}

- China- In China, the initial screening of the patients was done by 5G-enabled thermometers that send instant updates to all pandemic situations. Also, there were rings and bracelets that were connected to the Cloud Minds AI platform so that it could monitor all changes in the body (Liu \& Himss Greater China Team, 2020). Cloud Minds alone had deployed 100 robots in the country's hospitals. A few modified robots like Cloud Ginger (aka XR-1) and the Smart Transportation Robot carried food and medicine to patients from healthcare providers without any human contact. The smartphone app was first deployed in Hangzhou in collaboration with Alibaba. It assigned three colors to people-green, yellow and red on the basis of their travel and medical histories (Chaturvedi, 2020). Screening for infection China used free, web-based, and cloud-based tools to screen and direct individuals to appropriate resources. High-performance infrared thermal cameras set up in Taiwanese airports were used to capture thermal images of people in real time, rapidly detecting individuals with a fever (Drees, 2020). The prospects for efficiency offered by the internet of medical things (IoMT) and digital health (DH) continued to be examined in China. During the pandemic, an important innovation space had opened up for novel technologies. For example, the 5G network (Wang, et al, 2020). In China DH was used during this pandemic with the potential benefits such as: accessing to information, deliberating care, quality control, improving professionals' knowledge and skills, reducing health care cost and screening programs (Chen, et al., 2021). However, the DH had a wide range of negativity in the sense of breakdown of relationships between health professionals and patients that raised issues concerning the quality of health information, and organizational and bureaucratic difficulties (Hong, et al., 2020). In the future, with advancements in technology (eg; the application of 5G networks to improve the effect of video transmission) and improvement in the management experience of telemedicine by policymakers, the above mentioned limitations can be minimized, and telemedicine may become a sustainable, mainstream solution for both public health emergencies and routine medicine (Hjelm, 2005). Artificial intelligence technology was used in China to facilitate rapid diagnosis, risk prediction and cloud-based artificial intelligence used to detect COVID-19 (Liu \& Himss Greater China Team, 2020).

- South Korea: South Korea had integrated digital technology into government coordinated containment and mitigation processes: including surveillance, testing, contact tracing, and strict quarantine which could be associated with the early flattening of their incidence curves (Wang, et al., 2020). In Korea the Digital health technology has given more attention by physicians, patients, and healthcare industries to care and management assistant approach (Kim, et al., 2021). South Korea was digitalized about $50 \%$ in the implementation in hospital and early success in contract tracing, remotely monitoring the vital sign, reducing the risk of contamination for medical staff during the first wave of COVID 19 (Kim et al., 2021).

- USA: In the USA, a private company had used digital thermometers to collect real-time data on clusters of febrile illness (Drees, 2020), and a national study is capturing resting heart rate with a smartwatch application, which could be able to identify COVID-19 emerging outbreaks (Miller, et al., 2018). These initiatives were either enterprise-driven and were not integrated into policy and practice (Miller, et al., 2018). Those were basically information of personal protective equipment (PPE) using guidelines, staffing, ventilator usage and reliable and currently floating information. Some information was delivered throughout the nation focusing health-care authorities to increase the capacity, track the status of facilities, allocate health-care resources, and increase hospital bed capacity (Society of Critical Care Medicine, 2020).

- Europe: WHO Regional Director for Europe, stated that digital technologies have proved a powerful tool to fight with such a pandemic of COVID-19 (World Health Organization, 2020). These technologies transferred knowledge like a tsunami and raised empowerment to the people. In European countries mostly applied technologies like industry 4.0 technologies (Rodrigues, et al., 2021). All these were supported for contact tracing, gathering data, minimizing transmission, isolation in quarantine, rapid testing and care for every case without fear. Austria, Georgia and North Macedonia released national solutions for digital contact tracing in Europe at Andorra, Finland, Ireland and Portugal are solutions underway. 
Similarly, France, Italy and Sweden were also applied for digitalization of health technologies. France has started an artificial intelligence-based virtual phone to heap and respond to more than a thousand people at the same time during this COVID pandemic. During this pandemic time, Sweden developed a platform for health care professionals to report real time data on volumes of patients with covid-19. The health services, with the support of Microsoft developed the emergency COVID-19 response App (Meijer \& Webster, 2020).

- Italy: Italy applied AI-based technology, smartphone app and camera to capture vital statistics such as heart rate, heart rate variability, oxygen saturation and respiration rate in real time. Italy here was a huge catastrophic death at the beginning in Europe region Italy. The EU country Sweden used a telemedicine concept that has been used to support traditional care, particularly in rural settings, and is now being used for enhanced COVID-19 response (Kluge, 2020).

- South Africa: digital health technologies helped to fight from contamination using social media. These Digital platforms helped to build more resilient societies in terms of receiving and sharing the current information from the global. The WhatsApp services were important for the information of symptoms, preventive ways by the national health department. Majority Countries from South Africa including Kenya, Nigeria, Ghana, Uganda, and Togo were lacking to use the digital health technologies because of financial access (International Telecomunication Union, 2020). however, these were used some the social media Apps like, Twitter to elevate medical information from authoritative sources, Facebook messenger digitized social payments techniques with the support of Bank to reduce the risk of COVID-19 transmission through mobile, no matter where people are located (Jiang \& Ryan, 2020). Similarly, the country Cameroon used modern mobile devices with a higher gap during the pandemic to get notification of pandemic (International Telecomunication Union, 2020). Almost 95\% use radio as the most accessible across the country, 70\% users are on Facebook, 50\% for TV and YouTube. Twitter, 3G and $4 \mathrm{G}$ internet access and Wi-Fi services were also other sources of news and information mostly in the towns. The digital service has impacted Cameroonian society, politics and development, lifestyle as well as psychology (Mogessie, et al., 2020). The first case of COVID-19) was detected on March 6, 2020. At least of 70\% of people are alert about the disease which has created a huge fear and panic during the influx of foreign returnees because a lack of testing and the accurate of this testing and the open border with all countries (Europe, USA, China, Japan, etc.) (OECD/European Union, 2020), as other reasons can cause an outbreak in Cameroon. Many innovations were created to distance learning platforms, TV and radio communication tools as a substitute of digital health technology (Zhu, et al., 2020). People are subjected to the temperature measurement at the entries of workplaces, schools, public transport, etc. The free number call for any suspect case was used in order to diagnose and threaten. The ministry of health accesses the data of the infected person using mobiles via Twitter and Facebook from their working place (World Health Organization, 2020). Coronavirus disease 2019 (COVID-19) has accelerated the adoption of telemedicine in Cameroon in order to diagnose and treat people both near and far. The telemedicine program was used to screen for and educate patients on Covid-19. Also, traditional practitioners are treating Covid-19 by applying digitalization health technologies (TV, mobile phone) to access people or to have Rendez-Vous. Furthermore, the e-buy was increased as a pandemic outbreak across the country in 2020 in Cameroon. Thus, COVID-19 significantly impacted the life of Cameroonians by changing healthcare, quality education, economy and political issues (Béché, 2020).

- Canada: In Canada, mostly the private health insurers were implemented to offer virtual care services (Bhatia et al.,2021). Also, it had offered opportunities to clinical care (Sharma, et al., 2018), early disease detection by Online data sources (Budd, et al., 2020). The Information Technology Association of Canada has declared white paper on the acceleration of digital health technologies, procurement practices (ITAC Health, 2018).

- Singapore: In Singapore, people had their temperature measured at the entries of workplaces, schools, and public transport. The data from the thermometers was tracked and used to identify emerging hot spots and clusters of infection where testing could be initiated. Singapore applied mobile phones, Bluetooth for distance exchanges to each other and they recorded 
and stored for 21 days. The ministry of health accesses the data to identify the infected person using mobiles (Chua, et al., 2020).

- Latin America: While countries in Asia, Europe and Central America have invested efforts in technological advances in the identification and control of the epidemic, the countries of Latin America had scarce resources for the manufacture of protective equipment such as PPE and mechanical fans that are imported from other countries (Budd et, al., 2020). Health systems that were already fragile, suffered from fragmentation and segmentation in the face of various social and economic issues, as they were still facing Zika and the Chikungunya outbreaks. There was a concern about the availability of intensive care units, which were necessary for at least 20-25\% of patients hospitalized with COVID-19 - also, the availability of specific diagnostic tests, particularly real-time RT-PCR, it was a crucial challenge for early detection and prevention of COVID-19. The impact of the low technological structure directly affected the different ways of combating the covid-19 pandemic, when comparing, for example, access to 5G technology, which is only 3.2\% in Latin America, 15.0\% in AsiaPacific and 16.4\% in Eastern Europe, which widens the gap between countries (International Telecomunication Union, 2020).

- Brazil: Brazil was the first country in Latin America to have the first case of COVID-19 (Fiesco-Sepúlveda \& Serrano-Bermúdez, 2020). The country already had the health system of this region fragile in the face of other threatening diseases and is even more critical with the covid-19 pandemic. It faced the shortage of intensive care units, personal protective equipment (PPE) for health professionals and other medical supplies (Caetano et, al., 2020). The shortage was compounded by the lack of raw materials for manufacturing PPE or ventilators, covid-19 test kits, drugs and other medical supplies that are imported from the rest of the world (Rubin et, al., 2020). Challenges for providing telehealth services in rural areas were also discussed widely, such as workforce issues, quality of care concerns, reimbursement, licensure, and access to broadband services. Further, Geographic and originating site restrictions, Provider restrictions, service restrictions (Luciano, et al., 2020). Beaunoyer et al. (2020) summarized that the challenges of Internet speedy slower, inequalities distributions, autonomy of uses, connections of social support (eg; website mobile application and digital technology platforms), vulnerability of crisis of cyber security issues, lacking of eHealth knowledge, lack of family and peers support to adapt the new innovations, lacking updating in school curriculum, tutorial misinformation, lacking of electricity power, application gadget access, technology language barriers, myth of social medias.

- Australia: In Australia, digital technologies to support telehealth were proliferating during COVID-19 as include wearable devices, smart phones, smart homes and videoconferencing (World Health Organization, 2020). Smart homes were equipped with environmental and personal sensors that are interconnected using the Internet of things. The COVID-19 pandemic has been a catalyst for accelerated investment in digital health and greater coordination between governments and between private and public sector participants (Hii, et al., 2021; Bodulovic, et al., 2020). In March 2020, the Australian government made available Medicare Benefit Schedule items to cover the provision of telehealth services by doctors, nurses, midwives and allied health professionals (Hii, et al., 2021; Bhaskar, et al., 2020). The government also introduced electronic Pharmaceutical Benefit Scheme prescriptions as an alternative to paper ones and home delivery of prescriptions for vulnerable people and people in self isolation (Hii, et al., 2021) by the Australian Digital Health Agency (ADHA), which is responsible for the National Digital Health Strategy and operates My Health Record. In November 2020, following the release by the Department of Health of a National Contact Tracing Review, NSW, Victoria and the Australian Capital Territory (ACT) agreed to pilot a national digital data exchange mechanism that would allow the states and territories to share contact-tracing data for the covid-19 pandemic and future outbreaks and data sharing (Bodulovic et, al., 2020). Over 32.8 million telehealth services have been delivered and hundreds of thousands of electronic scripts have been written during this period (Hii, et al., 2021).

- United Kingdom: Digital technologies have been utilized during covid-19 as an alternative service to delay or to 
reduce the outbreaks of the disease (Whitelaw, et al., 2020). Telecommunication companies such as BT, Virgin Media, and Sky in the United Kingdom have agreed to support the National Health Services (NHS) in rolling out telehealth for healthcare practitioners and telehealth platforms continue to see increasing development and utilization as pressure from the COVID-19 pandemic pushes the need for remote services (Hutchings, 2020). In March 2020, the consultation of patients was done through an online platform, by videoconferencing or telephone services to reduce the infection of covid-19 (Rapson, 2020; NHS England, 2020). Only, in May 2020, almost 80,000 remote consultations had taken place through the platform (OECD/European Union, 2020). The NHS 111 online service was launched at the start of March 2020 to provide increased capacity for people needing advice about covid-19, and to free up NHS 111 call handlers' time (Rapson, 2020). Also, to communicate information about symptoms and guidance around self-isolation, the NHS worked with social media companies such as Google and Twitter to direct people to the correct advice and counter misinformation (OECD/European Union, 2020).

- Italy, Spain, Germany, France, Greece, Hungary, Ireland, Luxemburg, The Netherlands, Norway, Austria, Belgium, Croatia, Czech Republic, Denmark and Finland: Digital technologies such as videoconferencing, telephone services and online platforms were used to inform, to track or to reduce the infection of covid-19 (Sounderajah, et al., 2021). The health care practitioners shared their experiences to identify needs and demonstrate the urgent need for telemedicine solutions for efficient consultation and treatment of patients (Almathami, et al., 2020).

- India: Digital technologies increased quickly since the outbreaks of COVID-19 with the use of telephone services, video-conferencing and online platforms in order to inform, to consult and to take appointments (Bhaskar, et al., 2020). For example, in March 2020, more patients have turned to telemedicine and hence pushed the adoption of telemedicine in more healthcare practices. The Indian government issued new guidelines for telemedicine practice in March 2020 (Bhaskar, et al., 2020). This step-in public policy aims to give further guidance to the practice of telemedicine in India.

\subsection{Strengths, limitations and future scopes}

Digital technologies have proved to be powerful tools to fight COVID-19. The current coronavirus (COVID-19) pandemic is again reminding us of the importance of using telehealth to deliver care, especially as a means of reducing the risk of cross-contamination caused by close contact. For telehealth to be effective as part of an emergency response it first needs to become a routinely used part of our health system (Smith, et al., 2020). Hence, it is time to step back and ask why telehealth is not mainstreamed. In this article, we highlight key requirements for this to occur. Strategies to ensure that telehealth is used regularly in acute, post-acute and emergency situations, alongside conventional service delivery methods, include flexible funding arrangements, training and accrediting our health workforce (Ting, et al., 2020). Telehealth uptake also requires a significant change in management effort and the redesign of existing models of care (Tilahun, et al., 2021).

The human health had improved globally because of advanced technology. It's no different today. Advances in technology are continuing to push back the boundaries of disease (Mehl, et al., 2021). Digital technologies enable us to test for diabetes, HIV and malaria on the spot, instead of sending samples off to a laboratory (Mahmood, et al., 2020). 3D printing is revolutionizing the manufacture of medical devices, orthotics and prosthetics (Wesemann, at el., 2020). Telemedicine, remote care and mobile health are helping us transform health by delivering care in people's homes and strengthening care in health facilities. Artificial intelligence is being used to give paraplegic patients improved mobility, to manage road traffic and to develop new medicines. Machine learning is helping us to predict outbreaks and optimize health services.

Propelled by the global ubiquity of mobile phones, digital technologies have also changed the way we manage our own health. Today we have more health information - and misinformation - at our fingertips than any generation in history. Before we ever sit down in a doctor's office, most of us have Googled our symptoms and diagnosed ourselves-perhaps inaccurately. Similarly, digital technologies are being used to improve the training and performance of health workers, and to 
address a diversity of persistent weaknesses in health systems.

Telemedicine and eHealth significantly contribute to improve peoples' health and reduce health inequalities, generate and promote the appropriate use of technologies. Further, that can contribute to strengthening the health system, divert resources from non-digital approaches, to give more access to the health workers with clinical protocols, decision-support mechanisms or telemedicine consultations with other health workers from the multidisciplinary team (Hollander \& Carr, 2020).

In spite of the significant impacts of Digital Health (DH) with pandemic situations as described above, DH still needs to be identified and overcome in order to accelerate and deliver more effective and cost-efficient health care models. Dynamic digital health approach needs to be guided to prioritize primary health care (Fagherazzi, et al., 2020). No doubt digital health care can be effective at preventive health, reducing the burdens of pandemics. Additionally, further coming generations can be more technology friendly because of their growing up surroundings and digital era everywhere. And certainly, people will prefer to use in care in the home and other nonclinical sites, telemedicine for prison populations, rural telepsychiatry, postsurgical monitoring in an urban nursing home, telemedicine in a managed care system for telemedicine (Field, 1996).

This digital health implication rapidly be adopted by the professionals, doctors, staff which can influence the treatment line of COVID-19 and other similar pandemics or epidemics. It can be used to centralize all medical tools, devices and treatment processes. In future, the medical industry would grow and have to adapt to digital technologies to create a smart healthcare system and hence there is a need to change the software platform software devices to the latest ones. This revolution provides disruptive innovation to minimize the effect of COVID-19 virus (Donida, et al., 2021).

Most developing countries are already under tremendous stress because of financial constraints, enormous development challenges and technology innovation and knowledge deficiencies. COVID-19 which has disrupted every walk of life is having a multiplier effect on many countries, posing difficult governance choices. Reform and reorientation of the health system and structure is fundamentally important in dealing with the public health issues in the post COVID-19 period, and digital health could help in providing solutions (Javaid, et al., 2020).

Now it is time for a virtual doctor or telemedicine and telehealth that COVID-19 pushed for that practice in developing countries where the lack of health professionals is lacking. And it will be a new horizon in public health in rural regions like Nepal. All these above explaining innovative technologies can store, send and analyze the sensitive data of the healthcare system and can be useful for upcoming pandemics like COVID-19. On the time basis such technologies can be revolutionized rapidly (Nasreen, et al., 2020).

\subsection{Significant digital health technologies which may help in COVID-19 outbreaks}

Globally, many START-UPs are emerging and contributing to human beings to make their lifestyle and working environment. Therefore, digital health is considered a significant possible and well-known tool for coping with COVID-19. In many countries, artificial intelligence (AI) helped track people to make preparations for not more contamination or infection at a huge level (Vota, 2020). Also, it does analysis software for early diagnosis and assessment of virus symptoms, can detect, segment and produce 3D models of lung damage caused by COVID-19 based on analysis of CT images.

It is a fact that digital healthcare technologies have improved healthcare delivery with quick access of remote diagnosis with-out geographic boundaries to offer and get counseling services from the physician to the patients without any waiting time (da Silva, et al., 2021). Off-course the digital health technologies were a new path ways and adapted without delaying in comparisons other economically less access nations because the countries were not able to invest digital health technologies in their health system (McGuirk, et al., 2021). Also, it was the challenges to adapt as growing health care standardization because there was and any validation and was not approved in the health institution (Vandenberg, et al., 2021). 
COVID-19 has generated uncertainty and impacted in every health care instructions and is not easy to predict overall uses of digitalization to collaborative services globally (OECD/European Union, 2020). Thus, this COVID-19 has the technology uses in every sector and manage the such infrastructure to cope possible pandemic making access of digital health technologies. Off-course there is no doubt the number of limitations of access to the people, lacking of skills to use, security, validity and reliability.

Some digital technologies are illustrated below in the section of Significant Digital Health Technologies and used in COVID -19 pandemics which are most useful technologies during pandemic in different countries. Globally, rapidly developing a list of digital health technologies as solutions. Some of them are already being used and some are in the progress of developing to make less contamination of the coronavirus. According to Vota (2020); Javaid et al. (2020) and Nasreen et al. (2020) have summarized that there are more COVID-19 response global digital health solutions given in three categories: 1) Prevention 2) diagnosis and 3) treatment. Countries have used remote consultations, remote management of COVID-19 patients and digital tools to manage essential supplies (Whitelaw, et al., 2020).

As showed in Tabel 1, many health demands that emerged from the context experienced in the COVID-19 pandemic could be met as digital solutions were proposed and proved to be effective in addressing individual issues without increasing the risk of contamination for the people involved.

Table 1. Significant Digital Health Technologies and uses in COVID -19 pandemics.

\begin{tabular}{|c|c|c|}
\hline & Technology & USES \\
\hline 1 & COVIRA-App & $\begin{array}{l}\text { COVID-19 Risk Assessment and communication of his/ her own and family members, to measure the } \\
\text { personal and local risks in any geographical area in the country Nepal. https://risingnepaldaily.com/main- } \\
\text { news/covira-app-launched-to-measure-risks-of-covid-19. }\end{array}$ \\
\hline 2 & Worldometers & $\begin{array}{l}\text { Digital collection of current data from the global about the COVID-19. It does produce the daily basis } \\
\text { information of this pandemic. (https://www.worldometers.info/coronavirus/). }\end{array}$ \\
\hline 3 & $\begin{array}{l}\text { Person centered } \\
\text { software }\end{array}$ & $\begin{array}{l}\text { It is used for the care home and analyze data from this software and provide pre-emptive care of residents. } \\
\text { https://www.healtheuropa.eu/person-centred-software-developing-the-care-home-of-the-future/100554/ }\end{array}$ \\
\hline 4 & Digital Therapy & $\begin{array}{l}\text { Enabler to reduce mental health demand by using digital health therapy. It helps to minimize face to face } \\
\text { GP support, time and travel constraints and risk reduction form far distance during COVID - } 19 \text {. } \\
\text { https://www.pwc.co.uk/communications/assets/5g-healthcare.pdf. }\end{array}$ \\
\hline 5 & $\begin{array}{l}\text { Industry } 4.0 \\
\text { technologies }\end{array}$ & $\begin{array}{l}\text { Industry } 4.0 \text { technologies Internet of Things (IoT), Cloud Computing, Big Data Analytic, Cyber Physical } \\
\text { System, Cryptocurrency (Block chain), Artificial Intelligent, 3D printing, etc. are on industrial digital } \\
\text { revolution phase. These are creating Smart Factory. }\end{array}$ \\
\hline 6 & $\begin{array}{l}\text { Artificial } \\
\text { Intelligence }\end{array}$ & $\begin{array}{l}\text { AI can predict the outbreak and can also minimize or even stall the spread of the virus. The clinical trials } \\
\text { for drugs and vaccines against this virus can be optimized with the use of AI. It can be used to develop } \\
\text { robots, which can help undertake sanitization jobs and perform an online medical examination of the } \\
\text { people. The application of this technology is beneficial to manufacture the equipment required for the } \\
\text { healthcare system. https://www.weforum.org/agenda/2020/05/how-ai-and-machine-learning-are-helping- } \\
\text { to-fight-covid-19/. }\end{array}$ \\
\hline 7 & Holography & $\begin{array}{l}\text { It ensures the reduced exposure of the speakers, employees and clients to COVID-19. It feels like speakers } \\
\text { are live from their homes or offices virtually on a real event stage regarding COVID- } 19 \text {. In this time of } \\
\text { COVID } 19 \text { outbreak, when the workers are bound to stay at home, this technology of streaming } \\
\text { holographic events is becoming readily acceptable. https://www.prnewswire.com/news-releases/new- } \\
\text { holographic-virtual-events-will-reach-millions-amid-coronavirus-covid-19-crisis-301025496.html. }\end{array}$ \\
\hline 8 & Internet & $\begin{array}{l}\text { Internet became helpful to spread the information through lots of apps. Internet made entertainment and } \\
\text { kept busy to be isolated person to person, and medical staff from remote to monitor patients. }\end{array}$ \\
\hline 9 & Big data and analytics & Collection and comprehensive evaluation of data from many different sources. \\
\hline 10 & Autonomous robots & $\begin{array}{l}\text { Robots will eventually interact with one another and work safely side by side with humans and learn from } \\
\text { them. These robots will cost less and have a greater range of capabilities than those used in manufacturing } \\
\text { today. http://en.sia-plant.com/index.php?s=/Home/Article/detail/id/617.html. }\end{array}$ \\
\hline 11 & Simulations & $\begin{array}{l}\text { Setup times and increasing quality, plant operations to leverage real-time data and mirror the physical } \\
\text { world in a virtual model. http://www.et-edge.com/conferences/et-industry } 4 / \text {. }\end{array}$ \\
\hline
\end{tabular}




\section{Horizontal and vertical system integration}

\begin{tabular}{|c|c|}
\hline 13 & Biosensor \\
\hline 14 & Winix Technologies \\
\hline 15 & $\begin{array}{l}\text { Social medias: FB, } \\
\text { Twitter. You tube }\end{array}$ \\
\hline 16 & IT and MYHealth \\
\hline 17 & The cloud \\
\hline
\end{tabular}

18 3D Scanning

19 Autonomous Robot

20 Zoom, Video conference, webinar, WeMeet, Google meet

21 Remote controlled robots

22 Mobile health solutions

23 Patient personal health information

24 Artificial Intelligence videos

25 CPAP breathing devices

26 Biometric Bracelets

27 Emerald
With Industry 4.0, companies, departments, functions, and capabilities will become much more cohesive, as cross-company, universal data-integration networks evolve and enable truly automated value chains. https://www.bcg.com/publications/2015/engineered_products_project_business_industry_4_future_produc tivity_growth_manufacturing_industries.

Biosensor patch is useful to employ, cost saving, sensitive and to provide the accuracy information of clinical analysis and diagnosis of disease i.e., glucose monitor. It can early detection and monitor the disease. It may apply to early screening the COVID-19. However, it is under development to be validate ECG trace, temperature, respiration rate in that technology. https://www.ncbi.nlm.nih.gov/pmc/articles/PMC7267686/.

Winix Technologies which can use as Wireless Tracking System called Wi-MAP, can send data with best quality of Wi-Fi, Bluetooth and low energy sensors and users can follow the movements of people, location of public spaces like supermarkets, malls and hospital situations. https://www.monnit.com/Products/Sensor/?gclid=CjwKCAjwsan5BRAOEiwALzomX1nXwITfci7OBhw_ wimFbAZzChuTLemARNf6isdbvsStSJJskeUvjRoCo60QAvD_BwE.

All these were sources of getting information and making self- empowerment during pandemic. It also helped to change behavior of peoples and alert precaution of infections.

\section{It is used in to get information in health care information.}

More production-related undertakings will require increased data sharing across sites and company boundaries. At the same time, the performance of cloud technologies will improve, achieving reaction times of just several milliseconds. As a result, machine data and functionality will increasingly be deployed to the cloud, enabling more data-driven services for production systems.

3D scanning is used to convert the physical part in CAD digital data. This technology is successful for the reverse engineering processes. In medical, this technology is used for scanning the human body and its part as per precise dimension. 3D scanning output is used for the analysis for collecting data about its shape and appearance. This data can be used for a large number of applications and are also useful in developing video games and movies.

Police robot can be deployed for patrolling the areas to confirm that the people are following the orders of lockdown

Not only South Asian countries but also globally applied specific protocols dealing with screening at entry points, contact tracing, quarantine and isolation facilities etc. by using Zoom, Video conference, webinar, We Meet, to fight each other with COVID-19.

In China, it was used mouth swabs to test for the virus, ultrasound scans and listening to organs with a stethoscope and in Italy, the epicenter of Europe's COVID-19 outbreak, to deliver food and monitor routine health indicators. https://www.ncbi.nlm.nih.gov/pmc/articles/PMC7312924/.

Chatbot apps for communication and social interaction therapy, mobile health and wristwatch, Culturally and Linguistically Diverse (CALD) Assist for language barriers (clinicians to communicate with patients from non-English speaking background) of health care.

It is used delivery care, improving the emergency department patient journey, collection, storage, retrieval, analysis, and dissemination of digital patient data and to view and add to their own medical laboratories' records, discharge instruction, physicians note records. https://www.ncbi.nlm.nih.gov/pmc/articles/PMC3168326/.

Such videos can minimize the workload of doctors in hospital during this health crisis. It is useful to remotely monitor/observe/ surveillance and activities of the chronic disease and patient affected by virus. Also, it has high capacity to record data. https://www.wired.com/story/chinese-hospitals-deploy-ai-helpdiagnose-covid-19/).

Continuous Positive Airway Pressure (CPAP) breathing apparatus that pushes oxygen to the lungs without needing a ventilator. This solution uses 70 per cent less oxygen than earlier models. https://news.itu.int/3ways-innovative-tech-is-helping-during-the-covid-19-pandemic/.

It is used to track potential cases of COVID-19 in real time. Supplied by Ava, a Swiss medical technology company, skin temperature, breathing rate and heart rate and women monitor their fertility cycles. https://www.avawomen.com/ava-bracelet-for-covid-19/.

Emerald, was developed at MIT's Computer Science and ArtificIntelligence Laboratory (CSAIL). It does monitors health and sends the data to doctor and can reviews from home. https://thenextweb.com/neural/2020/04/15/mits-ai-powered-device-lets-doctors-monitor-coronaviruspatients-remotely/. 

and web application that enables health workers to notify health departments about new cases of epidemicprone diseases, detect outbreaks, and manage outbreak responses. Ghana Health Service and Nigeria Centre for Disease Control immediately activated and Nepal, national public health authorities are preparing to deploy SORMAS to the COVID-19 outbreak. https://www.path.org/articles/open-sourcesoftware-tool-helps-governments-monitor-covid-19/.

Source: Authors.

The digital solutions developed to increase access to information about the spread of the COVID-19 virus have proven to be powerful tools in the control and monitoring of infected people, and also in prevention by providing access to information to people with intellectual disabilities and populations that they live in an unfavorable geographic location, as showed in Table 2.

Table 2. Digital Solution for covid-19 Prevention.

\begin{tabular}{|c|c|c|}
\hline 1 & $\begin{array}{l}\text { nCoV Surveillance } \\
\text { System }\end{array}$ & $\begin{array}{l}\text { The Sri Lankan government developed a web-based DHIS } 2 \text { to collect the information from } \\
\text { passengers who does enter in the country from risk countries of COVID-19 surveillance. } \\
\text { This helps to detain demographics, immigration, symptoms of COVID-19 disease, and } \\
\text { possible contacts at all ports of entry, for local public health officers, based on their } \\
\text { geographic area. After } 14 \text { days, it captures symptoms of COVID-19 disease and any action } \\
\text { taken at the end of the surveillance period. }\end{array}$ \\
\hline 2 & $\begin{array}{l}\text { AskNivi Health } \\
\text { Messaging } 2\end{array}$ & $\begin{array}{l}\text { AskNivi is a free interactive chat service that makes it easy for people to learn about key } \\
\text { health topics and make informed and supported decisions about their health. New } \\
\text { conversations were added to share information from the WHO when people began asking } \\
\text { questions about COVID-19, and content will be expanded as the coronavirus situation } \\
\text { changes. }\end{array}$ \\
\hline 3 & $\begin{array}{l}\text { Harmony Data } \\
\text { Analysis }\end{array}$ & $\begin{array}{l}\text { Harmony is a rapidly deployable data integration and advanced analytics platform for } \\
\text { epidemic surveillance, case management and outbreak response. LMICs use Harmony to } \\
\text { rapidly improve their epidemic surveillance and response capabilities during infectious } \\
\text { disease outbreaks. Mozambique recently used these capabilities to mount an effective, data- } \\
\text { driven response to a cholera outbreak which reduced the daily number of new cases from } \\
400 \text { to zero in one month. }\end{array}$ \\
\hline 4 & $\begin{array}{l}\text { Inclusive } \\
\text { e-Learning }\end{array}$ & $\begin{array}{l}\text { Inclusive e-Learning meets individuals with intellectual disabilities at their level of } \\
\text { engagement and supports prevention efforts by educating everyone on good hygiene } \\
\text { practices. The Coronavirus Outbreak: eLearning Module was deployed on 16th March, to } \\
\text { educate the entire Special Olympics community about COVID-19 prevention ways. }\end{array}$ \\
\hline 5 & $\begin{array}{l}\text { Interactive FM } \\
\text { Radio }\end{array}$ & $\begin{array}{l}\text { Interactive radio that pairs AM and FM radio broadcasts with mobile phone responses is } \\
\text { a proven methodology for reaching rural and remote communities at scale in local } \\
\text { languages, to increase knowledge, change attitudes and practices. Interactive radio } \\
\text { interventions can answer listeners' questions, offer information, allay fears, dispel myths, } \\
\text { and survey listener's attitudes. }\end{array}$ \\
\hline 6 & HealthAlert & $\begin{array}{l}\text { It is a WhatsApp-based helpline to disseminate accurate and timely information about } \\
\text { COVID-19 from the National Department of Health to the South African public. It includes } \\
\text { a helpdesk with automated response and triage to answer user's queries and real-time data } \\
\text { insights for national policy decisions. }\end{array}$ \\
\hline 7 & $\begin{array}{l}\text { Artificial } \\
\text { Intelligence for } \\
\text { COVID-19 } \\
\text { Prevention }\end{array}$ & $\begin{array}{l}\text { Researchers are trying to aggregate coronavirus data from traditional sources, like social } \\
\text { media, newsfeeds, and airline ticketing systems to inform platforms like Health map, which } \\
\text { visually represents global disease outbreaks according to location, time, and infectious } \\
\text { disease agent. For example, Blue Dot used natural language processing of news reports, } \\
\text { machine learning of airline ticketing, and human epidemiologists' reviews to alerts its } \\
\text { clients of COVID-19 back in december, } \\
\text { progression.https://www.ictworks.org/artificial-intelligence-coronavirus-covid- } \\
\text { 19/\#.Xyt_gygzZeh }\end{array}$ \\
\hline
\end{tabular}


Below, in the Table 3, we present the main digital solutions developed for the rapid and effective diagnosis of COVID-19, which makes it possible to intervene in the transmission of the virus by minimizing its propagation.

Table 3. Digital Solutions for COVID-19 Diagnosis.

\begin{tabular}{|c|c|c|}
\hline 1 & Triage CheckUp & $\begin{array}{l}\text { Triage CheckUp is an automated risk assessment application for health workers that can check a } \\
\text { patient's symptoms and epidemiological factors using Korean coronavirus guidelines for front line } \\
\text { triage, and will soon be available in English, Korean, French and Vietnamese. A companion } \\
\text { application, Diagnosis CheckUp is a self-reporting tool for the general public to assess their risk } \\
\text { factors for coronavirus infection. }\end{array}$ \\
\hline & NoviGuide & $\begin{array}{l}\text { NoviGuide is a decision support platform that transforms static guidelines into point-of-care decision } \\
\text { trees for health systems to rapidly new deploy guidance and monitor use. Its dashboard helps visualize } \\
\text { clinician concern, an important indicator of disease spread in epidemics where testing is unavailable or } \\
\text { limited. }\end{array}$ \\
\hline 3 & OpenELIS Global & $\begin{array}{l}\text { OpenELIS Global is an open-source enterprise-level laboratory information system tailored for LMIC } \\
\text { public health laboratories that uses HL7 open standards. Open ELIS lab information system can help } \\
\text { with the receipt and tracking of potential COVID19 samples, assisting labs to process them effectively, } \\
\text { and report back findings to clinicians. }\end{array}$ \\
\hline 4 & $\begin{array}{l}\mathrm{Co} \\
\mathrm{Ma}\end{array}$ & $\begin{array}{l}\text { CommCare is an open-source mobile case management platform used by } 700,000 \text { frontline health } \\
\text { workers in } 60+\text { countries to track clients through a continuum of service delivery, commodities supply } \\
\text { chain, and patient messaging. CommCare allows non-engineers can build and adapt mobile } \\
\text { applications for contact tracing, data collection, decision-support, client tracking, SMS-interaction, and } \\
\text { map-based visualizations. }\end{array}$ \\
\hline 5 & $\begin{array}{l}\text { NoviGuid } \\
\text { Support }\end{array}$ & $\begin{array}{l}\text { NoviGuide is a decision support platform that transforms static guidelines into point-of-care decision } \\
\text { trees. Health systems can rapidly deploy guidance, monitor use and remove outdated content. } \\
\text { NoviGuide standardizes care and removes old protocols while capturing where and when clinicians are } \\
\text { accessing guidance. The Dashboard helps visualize clinician concern, an important indicator of disease } \\
\text { spread in epidemics. }\end{array}$ \\
\hline 6 & $\begin{array}{l}\text { Consult S } \\
\text { Medical I }\end{array}$ & $\begin{array}{l}\text { Consult Station is a fully connected medical booth that gives providers the ability to remotely examine } \\
\text { a patient using medical grade diagnostic instruments. Health practitioner scan examine and diagnose } \\
\text { many more patients without risking contamination of clinicians themselves. Video-based telemedicine } \\
\text { and the Consult Station gives remote clinicians to ability to take vitals, examine the heart, and lungs } \\
\text { and functions for a true remote diagnosis. }\end{array}$ \\
\hline 7 & $\begin{array}{l}\text { Artificial } \\
\text { Intelligence for } \\
\text { COVID-19Diagnosis }\end{array}$ & $\begin{array}{l}\text { Thousands of possible COVID-19 pneumonia patients have overwhelmed Chinese hospitals and } \\
\text { coronavirus testing facilities. Software created by Beijing startup Infer vision is in China on more than } \\
32,000 \text { potential cases to expedite diagnosis. Alibaba's research institute, Damo Academy, claims that } \\
\text { their trained AI model uses sample data from more than 5,000 confirmed cases to diagnose } \\
\text { coronavirus differences in CT scans with an accuracy of up to } 96 \% \text { within } 20 \text { seconds. } \\
\text { https://www.ictworks.org/artificial-intelligence-coronavirus-covid-19/\#.Xyt_gygzZeh }\end{array}$ \\
\hline
\end{tabular}

Source: Authors.

In the Table 4 it was listed the Digital Solutions for COVID-9 mitigation found in the papers included in this review. 
Table 4. Digital Solutions for COVID-9 mitigation.

\begin{tabular}{lll}
\hline $\mathbf{1}$ & WelTel & $\begin{array}{l}\text { WelTel is a secure, web-based, communication platform that uses SMS for maximum reach and voice or video } \\
\text { outreach when appropriate for integrated virtual care \& patient engagement. Cases and their contacts can be } \\
\text { connected to healthcare providers with data captured in a secure, consolidated database for real-time monitoring and } \\
\text { epidemiological evaluation. }\end{array}$ \\
\hline $\mathbf{2}$ & $\begin{array}{l}\text { mHero Health } \\
\text { Worker } \\
\text { Communicatio } \\
\text { ns }\end{array}$ & $\begin{array}{l}\text { mHero is a two-way mobile phone-based communication system that uses basic SMS to connect ministries of health } \\
\text { and health workers. Previously, IntraHealth International developed mHero with the government of Liberia and } \\
\text { UNICEF for the Ebola outbreak in Liberia, where over 10,000 people lost their lives. Now, Liberian ministry } \\
\text { officials are using mHero to send COVID-19 messages to health workers. }\end{array}$ \\
\hline $\mathbf{3}$ & $\begin{array}{l}\text { Community } \\
\text { Health Toolkit }\end{array}$ & $\begin{array}{l}\text { Community Health Toolkit is a global public good that includes open-source technologies for Community Health } \\
\text { Workers and supervisors. Community Health Toolkit can support Covid-19 response through community \& event- } \\
\text { based SMS/USSD check-ins by self-quarantined persons, educational messaging including protective measures for } \\
\text { CHWs \& communities, referrals \& treatment adherence, and data harmonization with other platforms. }\end{array}$ \\
\hline $\mathbf{4}$ & $\begin{array}{l}\text { HealthBeats } \\
\text { Remote } \\
\text { Monitoring }\end{array}$ & $\begin{array}{l}\text { HealthBeats is a global Remote Vitals Monitoring platform designed to bring healthcare to home. Users can take } \\
\text { their vital measurement with results transmitted real-time to care providers. For people under quarantine, } \\
\text { HealthBeats can track temperature, blood oxygen levels, and heart rate with automated and data collection. }\end{array}$ \\
\hline $\begin{array}{l}\text { Artificial } \\
\text { Intelligence for } \\
\text { COVID-19 } \\
\text { Treatment }\end{array}$ & $\begin{array}{l}\text { BenevolentAI and Imperial College London used algorithms connect molecular structure data to biomedical } \\
\text { information about relevant receptors and diseases to find potential drug targets. In silico Medicine recently } \\
\text { announced that their AI algorithms designed six new molecules that could limit COVID-19 pneumonia's ability to } \\
\text { virally replicate in cells. https://www.ictworks.org/artificial-intelligence-coronavirus-covid-19/\#.Xyt_gygzZeh }\end{array}$ \\
\hline
\end{tabular}

Source: Authors.

\section{Conclusion}

This review pointed out that digital health technologies in the context of the COVID-19 pandemic enabled adequate solutions with digital information from data collection to transfer and storage. The possibility of assisting in physical and social isolation in the treatment process of the infected patient, reduced the high risk of mortality and morbidity through teleservice, which established the new culture of teleservice. In addition, digital technologies developed and adapted to this context have demonstrated a significant capacity for remote operation and effectiveness to be applied to other health demands.

Emerging digital healthcare practices in healthcare during the COVID-19 pandemic marks the beginning of the digital age and revolutionizes the lives of societies and states by connecting the world and removing barriers and obstacles to healthcare. However, the digital division among the countries represents a barrier to the population to access DH, and in this way, the no access to the digital world is an obstacle to assure equity of rights accessing health services as started in the third United Nations Sustainable Development Goal, focused on health and well-being. Disseminating this knowledge and sensitizing managers, researchers to the development of new digital technologies and the use of existing ones can be powerful resources to fight new pandemics, such as the one from COVID-19 and Point out the digital division among the countries as a barrier to the population to access DH, and in this way, assure equity of rights accessing health services as stated in the Third United Nations Sustainable Development Goal, focused on health and well-being.

This study presented the contribution of digital health to diagnose, management and prevention the disease without the crowding the number of people in the care center and opened the eye to adapt the digital health in the care services. Digital health technologies were ease to clinical accuracy diagnostic process, self-diagnostic solution, early identification, with nonface-to-face preclinical care, consulting with the expert with-out delaying. It is essential that future research investigate and evaluate the implementation of digital technology applied during the COVID-19 pandemic in primary health care services, so that new guidelines can develop new practices with the same potential as that achieved at the secondary and tertiary levels in COVID-19 pandemic. Another challenge for researchers and managers is to make digital technology innovation accessible to the most vulnerable populations, such as indigenous peoples, people living in rural areas, prisons, who still do not benefit from 
such advances. Thus this study suggests that to apply the digital health technology to promote the better health care access in countries without delaying to fight the critical and unwanted situation of disease in coming days.

\section{References}

Almathami, H., Win, K. T., \& Vlahu-Gjorgievska, E. (2020). Barriers and Facilitators That Influence Telemedicine-Based, Real-Time, Online Consultation at Patients' Homes: Systematic Literature Review. Journal of medical Internet research, 22(2), e16407. https://doi.org/10.2196/16407

Bhatia, R. S., Chu, C., Pang, A., Tadrous, M., Stamenova, V., \& Cram, P. (2021). Virtual care use before and during the COVID-19 pandemic: a repeated cross-sectional study. CMAJ open, 9(1), E107-E114. https://doi.org/10.9778/cmajo.20200311

Bashshur, R., Shannon, G., Krupinski, E., \& Grigsby, J. (2011). The taxonomy of telemedicine. Telemedicine journal and e-health: the official journal of the American Telemedicine Association, 17(6), 484-94. https://doi.org/10.1089/tmj.2011.0103.

Bhaskar, S., Bradley, S., Chattu, V. K., Adisesh, A., Nurtazina, A., Kyrykbayeva, S., Sakhamuri, S., Yaya, S., Sunil, T., Thomas, P., Mucci, V., Moguilner, S., Israel-Korn, S., Alacapa, J., Mishra, A., Pandya, S., Schroeder, S., Atreja, A., Banach, M., \& Ray, D. (2020). Telemedicine across the globe-position paper from the COVID-19 pandemic health system resilience PROGRAM (REPROGRAM) international consortium (Part 1). Frontiers in public health, 8. https://doi.org/10.3389/fpubh.2020.556720.

Beaunoyer, E., Dupéré, S., \& Guitton, M. J. (2020). COVID-19 and digital inequalities: Reciprocal impacts and mitigation strategies. Computers in human behavior. 111, 106424. https://doi.org/10.1016/j.chb.2020.106424.

Béché, E. (2020). Cameroonian responses to COVID-19 in the education sector: Exposing an inadequate education system. International Review of Education, 66, 755-775. https://doi.org/10.1007/s11159-020-09870-x.

Benschoter, R. A., Garetz, C., \& Smith, P. (1967). The use of closed circuit TV and videotape in the training of social group workers. Social Work Education Reporter, 15(1), 18-20.

Bettinger, K. (2020). COVID-19: Emerging technologies are now critical infrastructure - what that means for governance. World Economic Forum, Davos. Retrieved from: https://www.weforum.org/agenda/2020/04/covid-19-emerging-technologies-are-now-critical-infrastructure-what-that-means-for-governance/.

Bodulovic, G., Wang, S., Morpurgo, M., \& Saunders, E. J. (2020). Telehealth around the world: a global guide. DLAPIPER, 1-145. https://www.dlapiper.com/en/italy/insights/publications/2020/11/telehealth-around-the-world-global-guide/.

Brem, A., Viardot, E., \& Nylund, P. A. (2021). Implications of the coronavirus (COVID-19) outbreak for innovation: Which technologies will improve our lives? Technological forecasting and social change, 163, 120451. https://doi.org/10.1016/j.techfore.2020.120451.

Budd, J., Miller, B. S., Manning, E. M., Lampos, V., Zhuang, M., Edelstein, M., Rees, G.,Emery, V. C., Stevens, M. M., Keegan, N., Short, M. J., Pillay, D., Manley, E., Cox, I. J., Heymann, D., Johnson, A. M., \& McKendry, R. A. (2020). Digital technologies in the public-health response to COVID-19. Nature Medicine, 26, 1183-1192. https://doi.org/10.1038/s41591-020-1011-4.

Caetano, R., Silva, A. B., Guedes, A. C. C. M., Paiva, C. C. N. D., Ribeiro, G. D. R.,Santos, D. L., \& Silva, R. M. D. (2020). Challenges andopportunities for telehealth during the COVID-19 pandemic: ideas on spaces andinitiatives in the Brazilian context. Cadernos de Saúde Pública, 36.

Caffery, L. J., Farjian, M., \& Smith, A. C. (2016). Telehealth interventions for reducing waiting lists and waiting times for specialist outpatient services: a scoping review. Journal of telemedicine and telecare 22(8), 504-512. https://doi.org/10.1177/1357633X16670495.

Chaturvedi, A. (2020). The China way: Use of technology to combat Covid-19. Geospatial world: advancing Knowledge for sustainability. Retrieved from: https://www.geospatialworld.net/article/the-sino-approach-use-of-technology-to-combat-covid-19./

Chen, M., Xu, S., Husain, L., \& Galea, G. (2021). Digital health interventions for COVID-19 in China: a retrospective analysis. Intelligent Medicine. https://doi.org/10.1016/j.imed.2021.03.001.

Chua, A. Q., Tan, M. M. J., Verma, M., Han, E. K. L., Hsu, L. Y., Cook, A. R., Cook, A. R., Teo, Y. Y., Lee, V. J., \& Legido-Quigley, H. (2020). Health system resilience in managing the COVID-19 pandemic: lessons from Singapore. BMJ global health, 5(9), e003317. https://doi.org/10.1136/bmjgh-2020003317.

da Silva, R. G. L., Chammas, R., \& Novaes, H. M. D. (2021). Rethinking approaches of science, technology, and innovation in healthcare during the COVID19 pandemic: the challenge of translating knowledge infrastructures to public needs. Health Res Policy Sys, 19(104): 1-9. https://doi.org/10.1186/s12961-02100760-8

Donida, B., da Costa, C. A., \& Scherer, J. N. (2021). Making the COVID-19 Pandemic a Driver for Digital Health: Brazilian Strategies. JMIR Public Health and Surveillance, 7(6), e28643.

Drees, J. (2020). Swedish health services tap Microsoft to build app that tracks COVID-19 patients and hospital capacity. Becker's health it. Retrieved from: https://www.beckershospitalreview.com/healthcare-information-technology/swedish-health-services-taps-microsoft-to-build-app-that-tracks-covid-19-patientshospital-capacity.html.

Fagherazzi, G., Goetzinger, C., Rashid, M. A., Aguayo, G. A., \& Huiart, L. (2020). Digital health strategies to fight COVID-19 worldwide: challenges, recommendations, and a call for papers. Journal of Medical Internet Research, 22(6), e19284.

Field, M. J. (1996). Telemedicine: A Guide to Assessing Telecommunications in Health Care. National Academies Press (US). https://doi.org/10.17226/5296. 
Fiesco-Sepúlveda, K. Y., \& Serrano-Bermúdez, L. M. (2020). Contributions of Latin America researchers in understanding of the novel coronavirus outbreak: a literature review. PeerJ, 8, e9332. https://doi.org/10.7717/peerj.9332.

Gershon-Cohen, J., \& Cooley, A. G. (1950). Telognosis. Radiology, 55(4), 582-587. https://doi.org/10.1148/55.4.582.

Hii, A., Jones, S., Lee, J., \& Mulheron, J. (2021). Digital health 2021: Australia. Gilbert + Tobin. https://cdn.brandfolder.io/3RTTK3 BV/as/2k9ksv6xngbt3zjhq96xh6xs/2021_Digital_Health_Australia.pdf.

Hjelm, N. M. (2005). Benefits and drawbacks of telemedicine. Journal of telemedicine and telecare, 11(2), 60-70. https://doi.org/10.1258/1357633053499886.

Hollander J. E., Carr B. G. (2020). Virtually Perfect? Telemedicine for Covid-19. The New England journal of medicine,382(18):1679-1681. 10.1056/NEJMp2003539.

Hong, Z., Li, N., Li, D., Li, J., Li, B., Xiong, W., Lu, L., Li, W., \& Zhou, D. (2020). Telemedicine During the COVID-19 Pandemic: Western China. Journal of medical Internet research. 22(5), e19577. https://doi.org/10.2196/19577.

Hutchings, R. (2020). The impact of Covid-19 on the use of digital technology in the NHS. Nuffield Trust, 1-23. https://www.nuffieldtrust.org.uk/files/202008/the-impact-of-covid-19-on-the-use-of-digital-technology-in-the-nhs-web-2.pdf.

International Telecomunication Union (ITU). (2020). Economic Impact of COVID-19 on digital infrastructure. https://www.itu.int/dms_pub/itu-d/opb/pref/DPREF-EF.COV_ECO_IMPACT-2020-PDF-E.pdf.

ITAC Health. (2018). Accelerating the adoption of digital health technologies in Canada [white paper]. https://technationcanada.ca/wpcontent/uploads/2020/10/Accelerating-Adoption-Health-Whitepaper-2018.pdf.

Javaid, M., Haleem, A., Vaishya, R., Bahl, S., Suman, R., \& Vaish, A. (2020). Industry 4.0 technologies and their applications in fighting COVID-19 pandemic. Diabetes \& metabolic syndrome, 14(4), 419-422.https://doi.org/10.1016/j.dsx.2020.04.032.

Jiang, N., \& Ryan, J. (2020). How does digital technology help in the fight against COVID-19? World Bank Blogs. Retrieved from: https://blogs.worldbank.org/developmenttalk/how-does-digital-technology-help-fight-against-covid-19.

Kichloo, A., Albosta, M., Dettloff, K., Wani, F., El-Amir, Z., Singh, J., Aljadah, M., Chakinala, R. C., Kanugula, A. K., Solanki, S., \& Chugh, S. (2020). Telemedicine, the current COVID-19 pandemic and the future: a narrative review and perspectives moving forward in the USA. Family medicine and community health, 8(3), e000530. https://doi.org/10.1136/fmch-2020-000530

Kim, H. S., Kwon, I. H., \& Cha, W. C. (2021). Future and Development Direction of Digital Healthcare. Healthcare Informatics Research, 27(2), 95-101.

Kluge, H. H. P. (2020). Statement - Digital health is about empowering people. World Health Organization [WHO]. https://www.euro.who.int/en/healthtopics/health-emergencies/coronavirus-covid-19/statements/statement-digital-health-is-about-empowering-people.

Liu, J., \& Himss Greater China Team. (2020). Deployment of IT in China's fight against the Covid-19 pandemic. Imaging Technology News. https://www.itnonline.com/article/deployment-health-it-china\%E2\%80\%99s-fight-against-covid-19-pandemic.

Luciano, E., Mahmood, M. A., \& Mansouri Rad, P. (2020). Telemedicine adoption issues in the United States and Brazil: perception of healthcare professionals. Health informatics journal, 26(4), 2344-2361.

Lurie, N., \& Carr, B. G. (2018). The role of telehealth in the medical response to disasters. Journal of the American Medical Association internal medicine, 178(6), 745-746. https://doi.org/10.1001/jamainternmed.2018.1314.

McGuirk, P., Dowling, R., Maalsen, S. \& Baker, T. (2020). Urban governance innovation and COVID-19. Geographical Research, 59(2): 1-8 https://doi.org/10.1111/1745-5871.12456

Machi, L.A., \& McEvoy, B.T. (2016). The Literature Review: Six Steps to Success. (3rd ed.). Corwin.

Mahmood, S., Hasan, K., Colder Carras, M., \& Labrique, A. (2020). Global Preparedness Against COVID-19: We Must Leverage the Power of Digital Health. JMIR public health and surveillance, 6(2), e18980. https://doi.org/10.2196/18980

Mehl G., Tunçalp, Ö., Ratanaprayul, N., Tamrat, T., Barreix, M., Lowrance, D., Bartolomeos, K., Say, L., Kostanjsek, N., Jakob, R., Grove, J., Mariano, B. Jr., \& Swaminathan, S. (2021). WHO SMART guidelines: optimising country-level use of guideline recommendations in the digital age. Lancet Digit Health, 3(4):e213-e216. doi: 10.1016/S2589-7500(21)00038-8.

Meijer, A., \& Webster, C. W. R. (2020). The COVID-19-crisis and the information polity: An overview of responses and discussions in twenty-one countries from six continents. Information Polity, (Preprint), 1-32

Miller, A. C., Singh, I., Koehler, E., \& Polgreen, P. M. (2018). A smartphone-driven thermometer application for real-time population- and individual-level influenza surveillance. Clinical infectious diseases: an official publication of the Infectious Diseases Society of America, 67(3), 388-397. https://doi.org/10.1093/cid/ciy073.

Mogessie, Y. G., Ntacyabukura, B., Mengesha, D. T., Musa, M. B., Wangari, M., Claude, N., Buntongyi, N., \& Lucero-Prisno III, D. E. et al. (2021). Digital health and COVID-19: challenges of use and implementation in sub-Saharan Africa. Pan African Medical Journal, 38(240): 1-3. 10.11604/pamj.2021.38.240.27948

Monnier A.J., Wright I. S., Lenegre J., Cameron D. J., \& Coblentz B. (1965). Ship-to-shore radio transmission of electrocardiograms and X-ray images. Journal of the American Medical Association, 193(12), 144-145. 
Murphy, R. L. Jr., \& Bird, K. T. (1974). Tele-diagnosis: a new community health resource. Observations on the feasibility of tele-diagnosis based on 1000 patient transactions. American journal of public health, 64(2), 113-119. https://doi.org/10.2105/ajph.64.2.113.

Nasreen, F., Fareed, A., \& Balouch, H. (2020). COVID-19 Crisis and Developing Countries: Digital Health Perspective. Commission on Science and Technology for Sustainable Development in the South (COMSATS). https://www.southsouth-galaxy.org/wp-content/uploads/2020/06/SViews-COMSATS.pdf.

NHS England. (2020). NHS 111 online to help people with coronavirus. NHS England. https://www.england.nhs.uk/2020/03/nhs-111-online-to-help-peoplewith-coronavirus/.

OECD/European Union. (2020). Health at a Glance: Europe 2020: State of Health in the EU Cycle. OECD Publishing. https://doi.org/10.1787/23056088.

Pathak, K. P., Gaire, T., \& Acharya, D. (2020). Novel Coronavirus Disease (COVID-19): Social Distancing, Isolation and Quarantine Are Key Success Factors of Nepal's Public Health Practices or Something Else. Kathmandu University medical journal, 18(70), 68-74.

Rapson, J. (2020). Covid sparks boom in digital hospital outpatient appointments. Health Services Journal. https://www.hsj.co.uk/technology-andinnovation/covid-sparks-boom-in-digital-hospital-outpatient-appointments/7027590.article.

Restás, Á., Szalkai, I., \& Óvári, G. (2021). Drone Application for Spraying Disinfection Liquid Fighting against the COVID-19 Pandemic—Examining DroneRelated Parameters Influencing Effectiveness. Drones, 5(3), 58. https://doi.org/10.3390/drones5030058.

Rheuban K. S., \& Krupinski E. A. (2018). History of Telehealth. In Nesbitt T. S., \& Katz-Bell J. (Eds.), Understanding Telehealth. McGraw Hill. https://accessmedicine.mhmedical.com/content.aspx?bookid=2217\&sectionid=187794434\#1158358708.

Rodrigues, W. C. Metodologia científica. 2007. http://uniesp. edu. br/sites/_biblioteca/revistas/20170627112856. pdf.

Rodrigues, T. V., Santos Filho, V. H. dos, Pontes, J., Resende, L. M. M. de \& Yoshino, R. T. (2021). Goverment initiatives 4.0: a comparison between industrial innovation policies for industry 4.0. Revista Gestão e Desenvolvimento. 18 (1):119-147. https://doi.org/10.25112/rgd.v18i1.2411.

Rubin, R., Abbasi, J., \& Voelker, R. (2020). Latin America and its global partners toil to procure medical supplies as COVID-19 pushes the region to its limit. Journal of the American Medical Association. 324(3):217-219. https://doi.org/10.1001/jama.2020.11182.

Sharma, A., Harrington, R. A., McClellan, M. B., Turakhia, M. P., Eapen, Z. J., Steinhubl, S., Mault, J.R., Majmudar, M.D., Roessig, L., Chandross, K.J., Green, E.M., Patel, B., Hamer, A., Olgin, J., Rumsfeld, J.S., Roe, M. T., \& Peterson, E. D. (2018). Using digital health technology to better generate evidence and deliver evidence-based care. Journal of the American College of Cardiology, 71(23), 2680-2690. https://doi.org/10.1016/j.jacc.2018.03.523.

Smith, A. C., Thomas, E., Snoswell, C. L., Haydon, H., Mehrotra, A., Clemensen, J., \& Caffery, L. J. (2020). Telehealth for global emergencies: Implications for coronavirus disease 2019 (COVID-19). Journal of telemedicine and telecare, 26(5), 309-313. https://doi.org/10.1177/1357633X209165677.

Society of Critical Care Medicine (2020). United States Resource Availability for COVID-19. https://sccm.org/getattachment/Blog/March-2020/United-StatesResource-Availability-for-COVID-19/United-States-Resource-Availability-for-COVID-19.pdf.

Sounderajah, V., Clarke, J., Yalamanchili, S., Acharya, A., Markar, S. R., Ashrafian, H., \& Darzi, A. (2021). A national survey assessing public readiness for digital health strategies against COVID-19 within the United Kingdom. Scientific reports, 11(1), 1-24. https://doi.org/10.1038/s41598-021-85514-w.

Tilahun, B., Gashu, K. D., Mekonnen, Z. A., Endehabtu, B. F., \& Angaw, D. A. (2021). Mapping the Role of Digital Health Technologies in Prevention and Control of COVID-19 Pandemic: Review of the Literature. Yearbook of medical informatics, 30(1), 26-37. https://doi.org/10.1055/s-0041-1726505

Ting, D., Carin, L., Dzau, V., \& Wong, T. Y. (2020). Digital technology and COVID-19. Nature medicine, 26(4), 459-461. https://doi.org/10.1038/s41591020-0824-5

Vandenberg, O., Martiny, D., Rochas, O., van Belkum, A., \& Kozlakidis, Z. (2021). Considerations for diagnostic COVID-19 tests. Nature reviews. Microbiology, 19(3), 171-183. https://doi.org/10.1038/s41579-020-00461-z

Vicentin, A. P., Simões, J.E., Bonilha, A. C., Lamoth, C., Andreoni, S., \& Ramos, L. R. (2020). Effects of combined digital inclusion and physical activity intervention on the cognition of older adults in Brazil. Gerontechnology. 19(3), 1-10. https://doi.org/10.4017/gt.2020.19.00308.

Vota, W. (2020). 10 Digital Health Technology Solutions for Global COVID-19 Response. Ictworks. https://www.ictworks.org/digital-health-solutions-covidresponse/\#.YWN2MxDMKCV.

Wang, C. J., Ng, C. Y., \& Brook, R. H. (2020). Response to COVID-19 in Taiwan: big data analytics, new technology, and proactive testing. Journal of the American Medical Association. 323(14), 1341-1342. https://doi.org/10.1001/jama.2020.3151.

Wesemann, C., Pieralli, S., Fretwurst, T., Nold, J., Nelson, K., Schmelzeisen, R., Hellwig, E., \& Spies, B. C. (2020). 3-D Printed Protective Equipment during COVID-19 Pandemic. Materials, 13(8): 1-9. doi:10.3390/ma13081997

Whitelaw, S., Mamas, M. A., Topol, E., \& Van Spall, H. G. C. (2020). Applications of digital technology in COVID-19 pandemic planning and response. The Lancet Digital Health, 2(8), e435-e440. https://doi.org/10.1016/S2589-7500(20)30142-4.

World Health Organization. (2010). Telemedicine: opportunities and developments in Member States: report on the second global survey on eHealth 2009. World Health organization [WHO]. 1-96. http://www.who.int/goe/publications/goe_telemedicine_2010.pdf.

World Health Organization. (2019). WHO guideline, Recommendations on Digital Interventions for Health System Strengthening. World Health Organization [WHO]. https://www.ncbi.nlm.nih.gov/books/NBK541905/. 
Research, Society and Development, v. 10, n. 14, e172101421776, 2021

(CC BY 4.0) | ISSN 2525-3409 | DOI: http://dx.doi.org/10.33448/rsd-v10i14.21776

World Health Organization. (2020). Statement on the second meeting of the international health regulations (2005) emergency committee regarding the outbreak of novel coronavirus $(2019-\mathrm{nCoV})$ Geneva: World Health Organization. https://www.who.int/news/item/30-01-2020-statement-on-the-secondmeeting-of-the-international-health-regulations-(2005)-emergency-committee-regarding-the-outbreak-of-novel-coronavirus-(2019-ncov).

Xiao, Y., \& Fan, Y. (2020). 10 technology trends to watch in the covid-19 pandemic. World Economic Forum, Davos. https://www.weforum.org/agenda/2020/04/10-technology-trends-coronavirus-covid19-pandemic-robotics-telehealth/.

Zhu, N., Zhang, D., Wang, W., Li, X., Yang, B., Song, J., Zhao, X., Huang, B., Shi, W., Lu, R., Niu, P., Zhan, F., Ma, X., Wang, D., Xu, W., Wu, G., Gao, G. F., Tan, W., \& China Novel Coronavirus Investigating and Research Team. (2020). A novel coronavirus from patients with pneumonia in China. The New England journal of medicine, 382(8),727-733. https://doi.org/10.1056/NEJMoa2001017. 